\title{
HUBUNGAN KEBIASAAN MEMBACA JARAK DEKAT DENGAN KELAINAN REFRAKSI MIOPIA PADA SISWA SMP NEGERI 7 PADANG
}

\author{
D.I SURYANTA \\ Akademi Refraksi Optisi YLTPK Padang
}

\begin{abstract}
In vision, the eye has various refractive errors. These refractive disorders include myopia, myopia is a condition in the eye that has excessive refraction power so that parallel rays that come are refracted in front of the retina. Many factors cause myopia, one of which is close reading. Reading is an activity that requires near vision. Children who read continuously for more than 30 minutes are more likely to develop myopia. This study aims to determine the relationship between the habit of reading at close range to myopia for grade IX students at SMP Negeri 7 Padang. The results showed that there was a relationship between history of close reading and myopia. Where Ho is rejected and $\mathrm{HI}$ is accepted, while the strength between variables in this study is assessed using adds ratio. The OR calculation result is 0.405 because OR $(0.405)<1$, this means the factor studied is a protective factor, namely students with a habit of reading at close range have a risk of suffering from myopia 0.4 times when compared with students who do not have the habit of reading distances. close. In other words, the habit of reading at close range is a risk factor, but the strength of the relationship is weak. Based on the results of this study, there are several suggestions, namely the need to maintain a safe distance between the eye distance and the material being read, in order to maintain eye health as a vital sense in vision and to prevent the causes of myopia.
\end{abstract}

Keywords: Near Distance Reading Habit, Myopia.

Abstrak: Dalam penglihatan, mata mempunyai berbagai macam kelainan refraksi. Kelainan refraksi tersebut antara lain miopia, Miopia adalah suatu keadaan mata yang mempunyai kekuatan pembiasan sinar yang berlebihan sehingga sinar-sinar sejajar yang datang dibiaskan di depan retina. Banyak faktor yang menyebabkan miopia, salah satunya ialah membaca jarak dekat. Membaca merupakan aktivitas yang memerlukan penglihatan jarak dekat.Anak-anak yang membaca terus menerus selama lebih dari 30 menit lebih mungkin terkena miopia. Penelitian ini bertujuan untuk Untuk mengetahui hubungan antara kebiasaan membaca jarak dekat terhadap miopia bagi siswa kelas IX di SMP Negeri 7 Padang. Hasil penelitian diperoleh keterangan bahwa bahwa terdapat hubungan antara riwayat membaca jarak dekat dengan miopia. Dimana Ho ditolak dan H1 diterima, sedangkan kekuatan antar variabel dalam penelitian ini dinilai dengan menggunakan adds ratio. OR hasil perhitungan adalah sebesar 0,405 karena OR $(0,405)<1$, hal ini berarti faktor yang diteliti merupakan faktor protektif yakni siswa dengan kebiasaan membaca jarak dekat mempunyai resiko untuk menderita miopia 0,4 kali lipat apabila dibandingkan dengan siswa yang tidak mempunyai kebiasaan membaca jarak dekat. Dengan kata lain, kebiasaan membaca jarak dekat merupakan faktor resiko, tetapi kekuatan hubungan nya lemah. Berdasarkan hasil penelitian ini, ada beberapa saran yaitu perlunya menjaga jarak aman antara jarak mata dengan bahan yang dibaca, guna untuk menjaga kesehatan mata sebagai indra vital dalam penglihatan dan untuk mencegah penyebab terjadinya miopia.

Kata Kunci: Kebiasaan Membaca Jarak Dekat, Miopia. 


\section{A. Pendahuluan}

Dalam penglihatan, mata mempunyai berbagai macam kelainan refraksi. Kelainan refraksi tersebut antara lain miopia, hipermetropia, dan astigmat. Kelainan refraksi merupakan gangguan yang banyak terjadi didunia tanpa memandang jenis kelamin, usia, maupun kelompok etnis. Data VISION 2020, suatu program kerjasama antara internasional agency for the prevention of blindness (IAPB) dan WHO, menyatakan bahwa pada tahun 2006 diperkirakan 153 juta penduduk dunia mengalami gangguan visus akibat kelainan refraksi yang tidak terkoreksi. Dari 153 juta orang tersebut, sedikitnya 13 juta diantaranya adalah anak-anak usia 5-15 tahun dimana prevalensi tertinggi terjadi di Asia Tenggara (Vision 2020 report, WHO2011).

Miopia adalah suatu keadaan mata yang mempunyai kekuatan pembiasan sinar yang berlebihan sehingga sinar-sinar sejajar yang datang dibiaskan di depan retina. Miopia terjadi karena bola mata terlalu panjang akibatnya kornea dan lensa menjadi cembung sehingga titik fokus sinar yang dibiaskan akan terletak di depan retina (Yani, 2008).

Terdapat dua etiologi yang berkaitan dengan miopia yaitu faktor genetik dan lingkungan, kedua faktor ini memegang peranan penting dalam perkembangan miopia (Widodo,2007). Bahwa membaca atau kerja dekat dalam waktu yang lama akan menyebabkan miopia. Membaca merupakan aktivitas yang memerlukan penglihatan jarak dekat.Anak-anak yang membaca terus menerus selama lebih dari 30 menit lebih mungkin terkena miopia di bandingkan dengan mereka yang membaca kurang dari 30 menit secara terus menerus (Ip, 2008). Sementara itu, anak-anak dengan kebiasaan membaca dengan jarak kurang dari $30 \mathrm{~cm}$ dalam waktu 2,5 jam lebih mungkin untuk menderita miopia dibandingkan dengan anak yang membaca dengan jarak $30 \mathrm{~cm}$ dalam waktu 2,5 jam. Penelitian di Australia perilaku, seperti pekerjaan dekat (membaca/belajar), dilaporkan bahwa persentase dalam perkembangan miopia sebesar $11,6 \%$ dari total variance serta membandingkan gaya hidup 124 anak dari etnis cina yang tinggal di Sidney, dengan 682 anak dari etnis yang sama di Singapura. Persentase anak yang mengalami miopia di Singapura $29 \%$ dan Sidney hanya 3,3\% yang menderita miopia. Faktor yang membedakan jumlah persentase anak Singapura yang lebih tinggi di bandingkan dengan anak Sidney dikarenakan anak Singapura jarang menghabiskan waktu diluar rumah (Robert van de berg, 2008).

Di Indonesia, prevalensi miopia mencapai $70-80 \%$ dan angka rata-rata nya meningkat di seluruh kelompok etnis. Prevalensi pada anak dengan riwayat kedua orang tua miopia sebesar 32,9\%, salah satu orang tua miopia sebesar 8,2\% dan dengan anak tanpa orang tua miopia sebesar 6,3\% (Widodo,2007). Penelitian lain mengungkapkan bahwa prevalensi miopia sekarang ini secara dominan karena faktor kebiasaan bukan karena genetik. Penelitian di Singapura mengamati bahwa anak yang menghabiskan waktunya untuk membaca, menonton TV, bermain video game dan menggunakan komputer lebih banyak mengalami miopia (Gunggenheim, 2007).

\section{B. Metodologi Penelitian}

Jenis penelitian bersifat dekskriptif kuantitatif, penelitian dilakukan untuk mengetahui cara penanggulangan dari hubungan kebiasaan membaca jarak dekat pada kelainan refraksi miopia pada siswa kelas IX di SMP Negeri 7 Padang. Metode ini di wujudkan oleh peneliti dengan cara melakukan wawancara kepada siswa dan pengumpulan data serta membuat kesimpulan tentang yang diamati. Populasi yang diambil peneliti adalah siswa kelas IX SMP Negeri 7 Padang dengan sampel sebanyak sebanyak 30 orang siswa.

\begin{tabular}{lll}
\hline E-ISSN: 2657-0300 & Lembaga Penelitian dan Penerbitan Hasil Penelitian Ensiklopedia & 195 \\
P-ISSN: 2657-0319 & &
\end{tabular}




\section{Hasil Dan Pembahasan}

1. Kelainan Refraksi Miopia Siswa Kelas IX di SMP Negeri 7 Padang

Tabel 1 Distribusi Frekuensi Kelainan Refraksi Miopia Kelas IX SMP Negeri 7

Padang

\begin{tabular}{|c|c|c|c|}
\hline NO & Penglihatan Kabur Saat Melihat & & \\
\hline 1 & Jauh & Frekuensi & $\%$ \\
\hline 2 & Ya & 22 & 73,3 \\
\hline & Tidak & 8 & 26,7 \\
\hline
\end{tabular}

Berdasarkan tabel 1 dapat diketahui bahwa 30 siswa didapatkan 22 orang $(73,3 \%)$ siswa mengalami kelainan miopia dan 8 orang $(26,7 \%)$ siswa tidak mengalami kelainan miopia yang disebabkan oleh kebiasaan membaca melainkan faktor keturunan.

\section{Kebiasaan Membaca Siswa Kelas IX di SMP Negeri 7 Padang}

Tabel 2 Distribusi Frekuensi Kebiasaan Membaca Siswa Kelas IX SMP Negeri 7

Padang

\begin{tabular}{|c|c|c|c|}
\hline NO & $\begin{array}{c}\text { Sering Membaca dalam Kondisi } \\
\text { Berbaring dan Membaca Buku } \\
\text { dengan Jarak Kurang dari 30 cm }\end{array}$ & Frekuensi & $\%$ \\
\hline 1 & Ya & 24 & 80,0 \\
\hline 2 & Tidak & 6 & 20,0 \\
\hline & Jumlah & 30 & 100,0 \\
\hline
\end{tabular}

Berdasarkan tabel 2 dapat diketahui bahwa 24 orang $(80,0 \%)$ siswa memiliki kebiasaan membaca dalam kondisi berbaring serta jarak membaca kurang dari $30 \mathrm{~cm}$ dan 6 orang $(20,0 \%)$ siswa tidak memiliki kebiasaan membaca dalam kondisi berbaring serta jarak membaca kurang dari $30 \mathrm{~cm}$. 


\section{Hubungan Kebiasaan Membaca Jarak Dekat dengan Kelainan Refraksi Miopia Siswa kelas IX SMP 32 Mukomuko}

Tabel 3 Hubungan Kebiasaan Membaca Jarak Dekat dengan Kelainan Refraksi Miopia Siswa kelas IX SMP 32 Mukomuko

\begin{tabular}{|c|c|c|c|c|c|c|c|}
\hline \multirow{2}{*}{ NO } & Kebiasaan & \multicolumn{4}{|c|}{ Kelainan Miopia } & \multicolumn{3}{c|}{ Jumlah } \\
\cline { 3 - 6 } & \multirow{2}{*}{\begin{tabular}{c} 
Membaca \\
\cline { 3 - 6 }
\end{tabular}} & \multicolumn{2}{|c|}{ Ya } & \multicolumn{2}{c|}{ Tidak } & \multirow{2}{*}{ N } & $\%$ \\
\cline { 3 - 7 } & & $\mathrm{N}$ & $\%$ & $\mathrm{~N}$ & $\%$ & & \\
\hline 1 & Ya & 20 & 83,3 & 4 & 16,7 & 24 & 100,0 \\
\hline 2 & Tidak & 2 & 33,3 & 4 & 66,7 & 6 & 100,0 \\
\hline & & & & & & & \\
\hline & Jumlah & 22 & 73,3 & 8 & 26,7 & 30 & 100,0 \\
\hline
\end{tabular}

Dari penelitian yang telah dilakukan pada siswa kelas IX di SMP Negeri 7 Padang tahun 2019 sebanyak 30 orang. Menurut Widodo (2007), Terdapat dua etiologi yang berkaitan dengan miopia yaitu faktor genetic dan faktor lingkungan, kedua faktor ini memegang peranan penting dalam perkembangan miopia. Hasil penelitian tabel 1 dapat diketahui bahwa 30 siswa didapatkan 22 orang $(73,3 \%)$ siswa mengalami kelainan miopia dan 8 orang $(26,7 \%)$ siswa tidak mengalami kelainan miopia yang disebabkan oleh kebiasaan membaca melainkan faktor keturunan. Hasil penelitian tabel 2 dapat diketahui bahwa 24 orang $(80,0 \%)$ siswa memiliki kebiasaan membaca dalam kondisi berbaring serta jarak membaca kurang dari $30 \mathrm{~cm}$ dan 6 orang $(20,0 \%)$ siswa tidak memiliki kebiasaan membaca dalam kondisi berbaring serta jarak membaca kurang dari $30 \mathrm{~cm}$.

Selain itu Rizky, dkk (2014) mengemukakan bahwa faktor-faktor yang saling berhubungan dengan miopia adalah faktor lama mata bekerja dan jarak dekat mata bekerja, sedangkan faktor keturunan tidak memiliki hubungan. Hasil $\mathrm{p}$ value dari faktor keturunan adalah 3,055, faktor lama mata bekerja $\mathrm{p}$ value 0,000 dan factor jarak dekat mata bekerja $\mathrm{p}$ value 0,038. Faktor-faktor yang memiliki hubungan dengan kejadian miopia adalah faktor lama mata bekerja dan faktor jarak dekat mata bekerja, sedangkan faktor yang tidak memiliki hubungan adalah faktor keturunan. Saminan (2013) juga menjelaskan bahwa beraktivitas dalam jarak dekat merupakan salah satu faktor resiko (efek) terjadinya miopia, semakin lama seseorang memfokuskan penglihatannya untuk melihat dekat semakin lama pula mata seseorang melakukan akomodasi, sehingga lama kelamaan mata akan lelah dan kondisi ini akan memicu pengaburan di retina dan mata menjadi tidak fokus.

Berdasarkan tabel 3 menunjukkan dari 24 orang mengalami miopia dengan riwayat membaca jarak dekat terdapat 20 orang $(83,3 \%)$ siswa lebih besar dibandingkan dengan 4 orang $(16,7 \%)$ siswa tidak mengalami miopia dengan riwayat tidak membaca jarak dekat tetapi disebabkan oleh faktor keturunan. Sedangkan siswa yang tidak memiliki riwayat membaca jarak dekat terdapat 6 orang diantaranya 2 orang $(33,3 \%)$ siswa mengalami miopia dengan riwayat membaca jarak dekat dan 4 orang $(66,7 \%)$ tidak mengalami miopia dengan riwayat memb aca jarak dekat karena disebabkan oleh faktor keturunan. Penelitian dilakukan oleh Robert van de Berg (2008), persentase anak yang memiliki riwayat membaca dekat mengalami miopia disingapura $29 \%$ dan di Sidney hanya 3,3\% yang menderita miopia, dan Widodo (2007) data dengan aktivitas melihat dekat degan menggunakan jam per hari menderita 
miopia sebesar 38,1\% di Yogyakarta. Berarti hasil penelitian yang saya lakukan memiliki persentase yang tinggi.

Hasil analisis untuk uji hubungan menyatakan ada hubungan antara riwayat membaca jarak dekat dengan miopia. Dimana Ho ditolak dan H1 diterima, sedangkan kekuatan antar variabel dalam penelitian ini dinilai dengan menggunakan adds ratio. OR hasil perhitungan adalah sebesar 0,405 karena $\mathrm{OR}(0,405)<1$, hal ini berarti faktor yang diteliti merupakan faktor protektif yakni siswa dengan kebiasaan membaca jarak dekat mempunyai resiko untuk menderita miopia 0,4 kali lipat apabila dibandingkan dengan siswa yang tidak mempunyai kebiasaan membaca jarak dekat. Dengan kata lain, kebiasaan membaca jarak dekat merupakan faktor resiko, tetapi kekuatan hubungan nya lemah. Hal ini dapat diartikan bahwa cara membaca, khususnya membaca jarak dekat merupakan salah satu faktor yang mempengaruhi dan memberikan kontribusi terhadap timbulnya miopia. Dikatakan pula, semakin dini mata seseorang terkena sinar terang secara langsung, maka semakin besar kemungkinan mengalami miopia (Ilyas, 2004). Kondisi ini menyebabkan perubahan adiptif pada kekuatan pembiasan dari lensa crystalline dan beberapa sistem yang

berhubungan, seperti tonus dari otot siliar menjadi hipertropi dan atropi, sehingga menyebabkan seseorang menjadi miopia (AOA, 2006). Selain itu, kelainan miopia dapat dikoreksi dengan menggunakan lensa sferis negatif atau lensa cekung (concavellens) sehingga cahaya yang datang akan disebarkan oleh lensa koreksi sebelum masuk kedalam mata, sehingga cahaya yang masuk dapat jatuh ke titik fokus lebih posterior atau tepat pada retina (Guyton A.C. dan Hall, J.E., 2007).

\section{Simpulan}

Berdasarkan hasil penelitian dapat ditarik kesimpulan bahwa terdapat hubungan antara riwayat membaca jarak dekat dengan miopia. Dimana Ho ditolak dan H1 diterima, sedangkan kekuatan antar variabel dalam penelitian ini dinilai dengan menggunakan adds ratio. OR hasil perhitungan adalah sebesar 0,405 karena OR $(0,405)<1$, hal ini berarti faktor yang diteliti merupakan faktor protektif yakni siswa dengan kebiasaan membaca jarak dekat mempunyai resiko untuk menderita miopia 0,4 kali lipat apabila dibandingkan dengan siswa yang tidak mempunyai kebiasaan membaca jarak dekat. Dengan kata lain, kebiasaan membaca jarak dekat merupakan faktor resiko, tetapi kekuatan hubungan nya lemah.

\section{Daftar Pustaka}

American Optometric Association (AOA). (2006). Optometric Clinical Practice Guildeline: Care of the Patient with Myopia. St. Louis: American Optometric Association.

Guyton A.C. dan Hall, J.E. (2007). Buku Ajar Fisiologi Kedokteran. Jakarta : EGC.

Guggenheim, J.A 2007.Correlation in refractive errors between sublings in the Singapore cohort study of risk factor myopia.http://proquest.umi.com diakses 02 juli 2019.

Ilyas HS. (2004). Kelainan Refraksi \& Koreksi Penglihatan. Jakarta: FKUI. 
Rizky, E. N. A. K, Silvia, E, \& Utami D. (2014). Faktor-faktor yang Menyebabkan Miopia pada mahasiswa Fakultas Kedokterangan Angkatan 2009 Universitas Malahayati. Jurnal Ilmu Kedokteran dan Kesehatan. Vol. 1 No. 2. pp.89-96.

Robert Van De Berg., Mohamed Dirani., Christine Y. Chen., Nicholas Haslam, and Paul N. Baird. 2008. Myopia and Personality : The Genes in Myopia (GEM) Personality Study. Ophtalmology \& visual Science.

Saminan. (2014). Efek Bekerja dalam Jarak Dekat terhadap Kejadian Miopia. Jurnal Kedokteran Syiah Kuala. Vol. 13. No. 3. pp. 187-191.

VISION 2020 The Right To Sight. Refraktive error. Hal 15-12..

Yani, Ahmad Dwi. 2008. Kelainan Refraksi dan Kacamata. Surabaya Eye CLINIC. 